\title{
Developing and Optimization of Fragmented Electroactive Biofilm Reactor (FAB) to Increase Microbial Fuel Cell Bioelectricity Generation and Treatment Performance
}

\author{
Tesfalem Atnafu ( $\nabla$ tesfalem_atnafu@yahoo.com ) \\ Addis Ababa University https://orcid.org/0000-0001-5183-4337 \\ Seyoum Leta \\ Addis Ababa University
}

\section{Research}

Keywords: fixed electroactive biofilm (FAB), electroactive biofilms (EABs), microbial fuel cell (MFC), Open circuit voltage (OCV)

Posted Date: January 5th, 2021

DOl: https://doi.org/10.21203/rs.3.rs-138288/v1

License: (c) (1) This work is licensed under a Creative Commons Attribution 4.0 International License. Read Full License 


\title{
Developing and optimization of fragmented electroactive biofilm reactor (FAB) to increase microbial fuel cell bioelectricity generation and treatment performance
}

\author{
Tesfalem Atnafua, ${ }^{\mathrm{a}, \mathrm{b}}$, and Seyoum Leta ${ }^{\mathrm{a}}$ \\ ${ }^{a}$ Center for Environmental Science, Addis Ababa University, P.O.Box 1176 Addis Ababa, \\ Ethiopia \\ ${ }^{\mathrm{b}}$ Department of Biological Science, College of Natural and Computational Science, Mettu \\ University, P.O.Box 318, Metu, Ethiopia \\ *Corresponding author, E-mail address: tesfalem_atnafu@yahoo.com
}

\begin{abstract}
Background: Microbial fuel cells (MFCs) drawbacks are anode (cathode) limitation and electrochemical loss. Engineering the biofilm for enhanced attachment to the electrode is the prospect of MFC. Recent studies, recommend the formation of thick anode biofilm that could result in a synergetic effect between microbial communities. To address these issues, a microbial electrode jacket dish (MEJ-dish) was invented that supports microbial growth over the anode electrode surface. The MFC reactor with MEJ-dish was hypothesized to develop a fragment of biofilm (thick and thin) across the electrode. This reactor is called a fragmented electroactive biofilm-microbial fuel cell reactor (FAB-MFC).

Results: The maximum voltage generated $(0.87 \mathrm{~V})$ was recorded in FAB-MFC. In addition, during the first 3-10 days, the FAB system enables to significantly $(\mathrm{p}<0.05)$ maximize the voltage generation at $\mathrm{pH}$ variation from 6.5 to 7.5. However, at alkaline $\mathrm{pH} 8.5$, the FAB system generates a lower voltage relative to non-FAB. On the contrary, in FAB reactors the COD removal was improved regardless of $\mathrm{pH}$ variation (6.5-8.5). This shows, unlike voltage generation, the biofilms (either electroactive or not) formation were vital for COD removal even without voltage generation. At acidic and neutral $\mathrm{pH}$ (7.5), the fragmented (hybrid) biofilm formation across the bioelectrode (anode) could not only important for voltage generation but also contributes to the effective functioning of electroactive biofilm (EABs) growth and development by reducing the effect of $\mathrm{pH}$ variation. To address this contradictory effect of increasing COD removal associated with the lower voltage at higher $\mathrm{pH}$, might be to use both FAB and non-FAB in a single MFC reactor. There might be a mutualistic effect across the bioelectrode biofilms.

Conclusions: This study showed that the voltage generated was significantly higher in FAB-MFC as compared with non-FAB-MFC setup within limited $\mathrm{pH}$ (6.5-7.5); relatively, COD removal was enhanced within wider $\mathrm{pH}$ 6.5-8.5. This supports the conclusion that biofilm formed across the $\mathrm{FAB}$ was vital for COD removal, even though not participated in voltage generation. However, this might be affected by the degradable organic content and the nature of the microbial community in the inoculum and domestic wastewater, which requires further studies.
\end{abstract}

Keywords: fixed electroactive biofilm (FAB), electroactive biofilms (EABs), microbial fuel cell (MFC), Open circuit voltage (OCV) 


\section{Background}

The electrochemical fuel cell was discovered early in 1839, but the bioelectricity generation through the microbial fuel cell (MFC) was known in 1910 through Michael C. Potter's observation (Flimban et al. 2019). However, still, this technique is facing a critical challenge from commercialization and requires research on several aspects of MFC that requires innovative approach on reactor design, MFC materials fabrication, terminal electron acceptor, membrane, etc., which should be investigated in small scales (Koroglu et al. 2019). The key research questions for MFC through the hybrid system are (1) can exoelectrogen bacteria bioengineered to more efficient ones?; and (2) can scientists develop materials, which are sufficiently low cost and easily regenerates both energy production and wastewater treatment?

MFC generates electricity from renewable sources such as wastewater or agricultural residue (Vicari et al. 2016). MFC consists of two major parts anode and cathode, which have membrane (separated by membrane or salt bridge) or membraneless (without membrane). The anode is a negative terminal, electrons flow through an external circuit that connects anode and cathode, while proton exchange occurs via the intermediate substance (Logan et al. 2006). There are two different types of cathode: air and aqueous; the air cathodes reduces the MFC costs because it does not require extra energy to pump air to the water in the cathode (Liu and Logan 2004). MFC applicable in a wide area, biosensor, wastewater treatment, and seawater desalination. Biofilm coated electrodes for bioelectricity generation attracted a wide area of research. Microbial fuel cells recovering energy from wastewater are a future promising renewable energy source (Vicari et al. 2016).

Four mechanisms enable to transfer of an electron from the bacteria cell membrane to the electrode. These are (1) indirect electron transfer involving the oxidation of microbial metabolism at the anode; (2) indirect electron transfer through chemical mediators; (3) indirect electron transfer through bacteria own mediators; and (4) direct electron transfer by bacteria to the conductive electrode (Borole et al. 2011; Logan et al. 2006; Patil et al. 2012; Ucar et al. 2017). The recent publication reveals additional two types of electron transfer in EABs by G. sulfurreducens biofilms grown on anodes (biofilm anodes) were proposed superexchange that involve electron-transfer among a network of cytochromes (Strycharz-Glaven et al. 2011), and metallic-like conductivity by the biofilms that can conduct over a distance of centimeters and the biofilm conductivity increased by processing (Malvankar et al. 2011). However, Strycharz and Tender (2012) argue as there was no evidence to support metallic conductivity.

MFC differs from the conventional electrochemical cell (such as batteries, and supercapacitors) and low-temperature fuel cell (direct methanol fuel cell or proton exchange membrane fuel cell). In MFC; electrolysis is conducted through the abiotic process (electroactive bacteria or protein) (Borole et al. 2011; Erable et al. 2010), which operate at room temperature within the range between $15{ }^{\circ} \mathrm{C}$ and $45{ }^{\circ} \mathrm{C}$; working in neutral $\mathrm{pH}$ conditions; uses a different range of biomass (liquid or solid) as anodic fuel, and the life cycle is environmentally benign. Hence, the anode biofilms are not only essential for electricity generation and might have a mutualistic or antagonistic effect in the MFC ecology, which depicts unusual phenomenon that requires further study (Mancílio et al. 2020). 
The major drawback of membraneless MFC (ML-MFC) is the diffusion of oxygen from cathode to anode that hampers the energy yield (Jang et al. 2004). The optimum biofilm formation time is 7 days (Arbianti et al. 2018). The formation and growth of anode biofilms in MFC are highly sensitive to oxygen (Yang et al. 2019). In which the anode biofilm forms two layers, the inner layer generates electricity, whereas the outer layer consumes oxygen. On the contrary, in pure Geobacter sulfurreducens the highest electrochemical activity was achieved within thin biofilm thickness of $\sim 20 \mu \mathrm{m}$, but as the thickness increases further the performance decline due to the dead mass accumulate in the inner side of the electrode and develop resistance (Sun et al. 2016); hence, live-cell mass rather than the biofilm thickness is responsible for the high current generation. Enhancing MFC bioelectricity generation, and examining the power generation under partially oxygenated conditions are just a few of these and are subjected to exciting research in the coming years (Borole et al., 2011). According to Ter Heijne et al. (2020), EABs study is at an earlier stage and most study focuses on how electron transfer but there was an urgent research gap, (1) how to steer biofilm formation in MFC to increase energy generation and (2) lack clear understanding of different EABs phenomenon. In search of these challenges, Michie et al. (2020) noted that 3D carbon materials influence biofilm development, and robust biofilm is important that have a direct effect on electrogenic nature and increase power generation.

The initial step in MFC is the acclimatization of biofilm on the electrode surface (Kumar et al. 2018). This is followed by colonization of the biofilm to form exoelectrogen biofilm and transfer electrons to the anode. During this process, some proteins specifically pili and outer membrane $\mathrm{c}$ type cytochromes (OMC c-Cyts) such as OmcZ, and OmcS facilitate the biofilm formation. In the anode biofilm, non-electrogenes are essential to enhance MFC power production by creating the anaerobic condition for electroactive bacteria. Each species on the anode surface biofilm play a synergetic effect in energy generation and pollutant removal (Guo et al. 2020). Hence, increasing the anode biofilm mixed community might simultaneously improve energy generation and wastewater treatment for MFC, which were not studied. In addition, the major limitation barrier to maximize MFC is: first, during the MFC process, the $\mathrm{H}^{+}$accumulates at the anode that results in high $\mathrm{pH}$. The second method was to enhance the growth and development of anode respiring bacteria (ARB) or exoelectrogen during the MFC process (He et al. 2017; Santoro et al. 2017). The non-electrogenic microbes are essential for the microbial ecology of MFCs. They provide a local anaerobic environment in mixed culture systems facilitating higher power production using anaerobic electroactive bacteria when compared to pure cultures grown in aerobic conditions (Borole et al. 2011; Guo et al. 2020).

Therefore, the major objective of this research work was to develop eco-friendly domestic wastewater treatment that simultaneously enhances energy recovery and treatment (with a singlephase process). The microbial electrode jacket dish (MEJ-dish) was invented to overcome these limitations and increase microbial biofilm development on the electrode surface and maximize voltage generation and treatment performance. The MEJ function as a bioelectric film dish to culture and grow a mixed microbial community including exoelectrogens or anode respiring bacteria (ARB) inside the MFC reactor. This was expected to shield the strict anaerobic electroactive biofilms (EABs) from oxygen contamination and contribute to a symbiotic relationship between EABs. Additionally, it was used for analyzing the effect of biofilm growth over the electrode with the microbial supporting structure. 


\section{- Materials and methods}

\section{Experimental setup}

A lab-scale two-chambered microbial-fuel cell reactor (MFC) was constructed. Several parameters were considered for the design of the microbial fuel cell reactor (MFCR). These include selecting substrate type to feed MFC, $\mathrm{pH}$, temperature, organic loading rate, HRT, operation (batch versus continuous), effluent collection, and processing mechanism. Additional MFC design parameters included were biogas collection and storage mechanisms, gas purification, pretreatment of the wastewater, agitation mechanisms, competitors inhibition, and biofilm supporting media for successful adaptation of exoelectrogens. Two types of FAB-MFC reactors were designed, the first the optimization study using a thermostat water bath (Fig. 2), and the second set up for mini benchtop MFC reactor (Fig. 1).
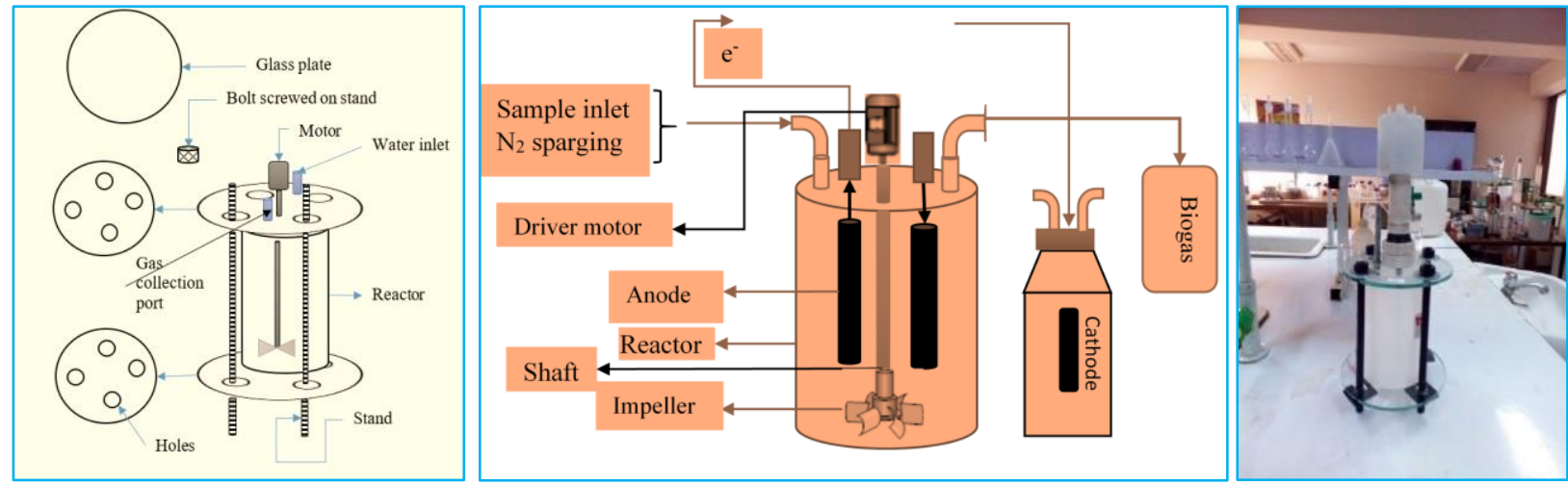

Fig. 1 Schematic diagram of mini benchtop microbial fuel cell reactor (mbMFC), the constructed lab-scale microbial fuel cell

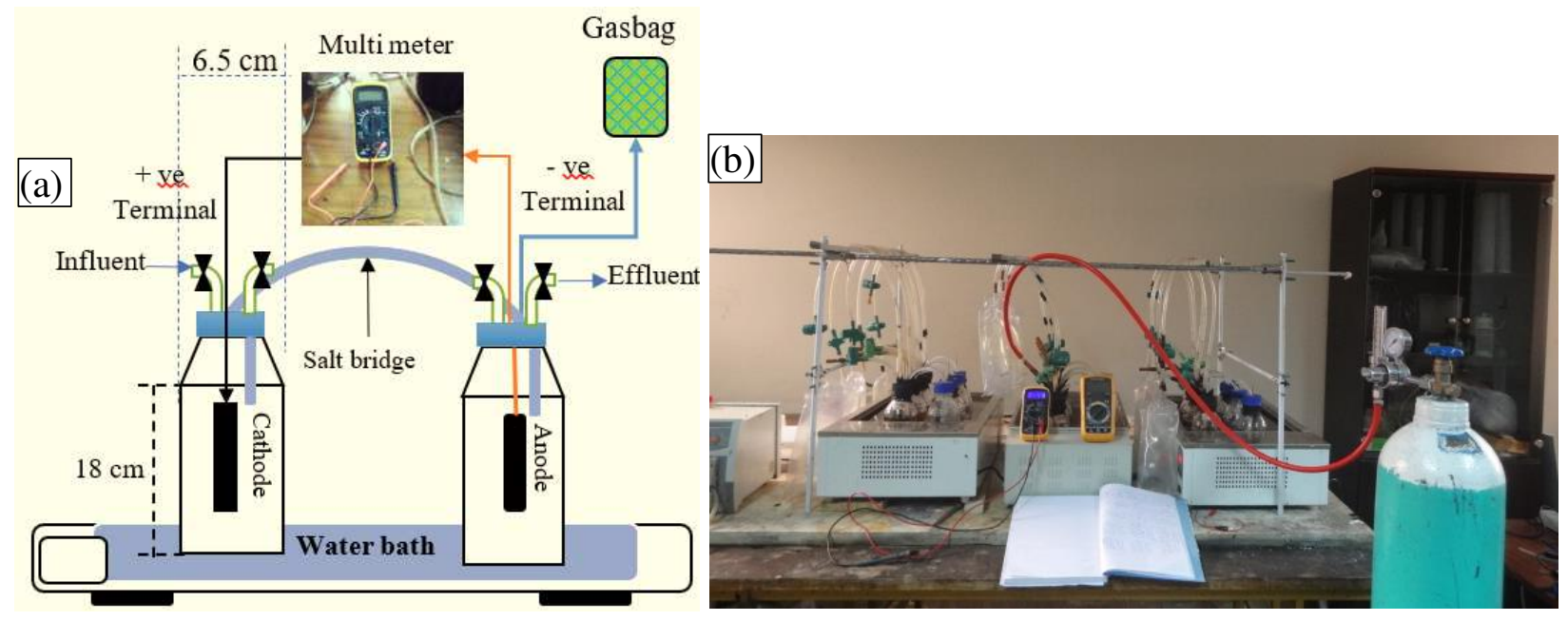

Fig. 2 Schematic diagram of semi-continuous H-type FAB-MFC optimization setup

In the first setup, the H-type double chamber MFC reactor from Vicari et al. (2016) was modified to design a semi-continuous microbial fuel cell reactor (MFC) for optimization study. In both cases, the FAB-MFC reactor consists of anode and cathode. A graphite $1 \mathrm{~cm}$ in diameter and 12.5 
$\mathrm{cm}$ in length with a surface area of $40.84 \mathrm{~cm}^{2}$ was placed at the anode. Similarly, the air-cathode was constructed from $12.5 \mathrm{~cm}$ by $1 \mathrm{~cm}$ graphite electrode. The anode and cathode were connected using a salt bridge. A graphite $1 \mathrm{~cm}$ in diameter and $12.5 \mathrm{~cm}$ in length with a surface area of 40.84 $\mathrm{cm}^{2}$ was placed at the anode. Similarly, the air-cathode was constructed from $12.5 \mathrm{~cm}$ by $1 \mathrm{~cm}$ graphite electrode.

The second FAB reactor consists of an overhead DC motor (24 V) stirrer, sample inlet, nitrogen gas sparging valve, and biogas (methane, $\mathrm{CO}_{2}$, etc.) collection port. A pinched impeller attached to the shaft was used to stirrer the solution in the reactor. The speed of the motor driver was controlled using DC power supply unit (BK-1502DD, BAKU, China). The total working volume of the reactor was $800 \mathrm{~mL}$, with a dimension of $8.5 \mathrm{~cm}$ x $6.5 \mathrm{~cm}$ x $18 \mathrm{~cm}(\mathrm{WxDxH})$. The designed microbial fuel cell reactor (MFCR) was autoclavable, featuring multiple overhead ports and a vertically agitating drive motor. It was a type of anaerobic completely stirred tank reactor (ACSTR) with benchtop mini size, and the operation was modified for bioelectricity production from domestic wastewater.

Salt bridge was prepared using agar powder (5\%) and 1M KCl (Ankur and Shipra 2018; Sevda and Sreekrishnan 2012). Initially, distilled water was allowed to warm on a hot plate with a magnetic stirrer; 5\% (w/v) agar powder and $1 \mathrm{M} \mathrm{KCL}$ was added. The mixture was stirred till a thick molten salt bridge was formed. Then carefully without forming air bubbles, the molten salt bridge mixture was poured into a plastic pipe (made from high-density polyethylene) closed in one end using cello tape and bent to have a U-shape, then it was placed in a $2 \mathrm{~L}$ beaker to maintain the shape and cool at room temperature. Salt bridge without any tiny air bubbles was used for the experiment. However, if any air bubbles were formed inside the tube, then the salt bridge was refilled before used for the experiment otherwise discarded.

\section{Synthesis of microbial electrode jacket (MEJ) for MFC}

Bioelectrode modification was carried out for enhancing the MFC efficiency from domestic wastewater. Microbial electrode jacket dish (MEJ-dish) or Jacketed microbial electrode (JMEdish) was designed and constructed. The designed MEJ-dish was expected to functions as an electroactive biofilm growth support. As shown in Fig. 3a, thick biofilms were hypothesized to form over MEJ-dish and thin film across the electrode, overall that forms fragmented (fixed) biofilm (FAB-MFC), and the reactor without MEJ-dish was called non-FAB or MFC (Fig. 3b).

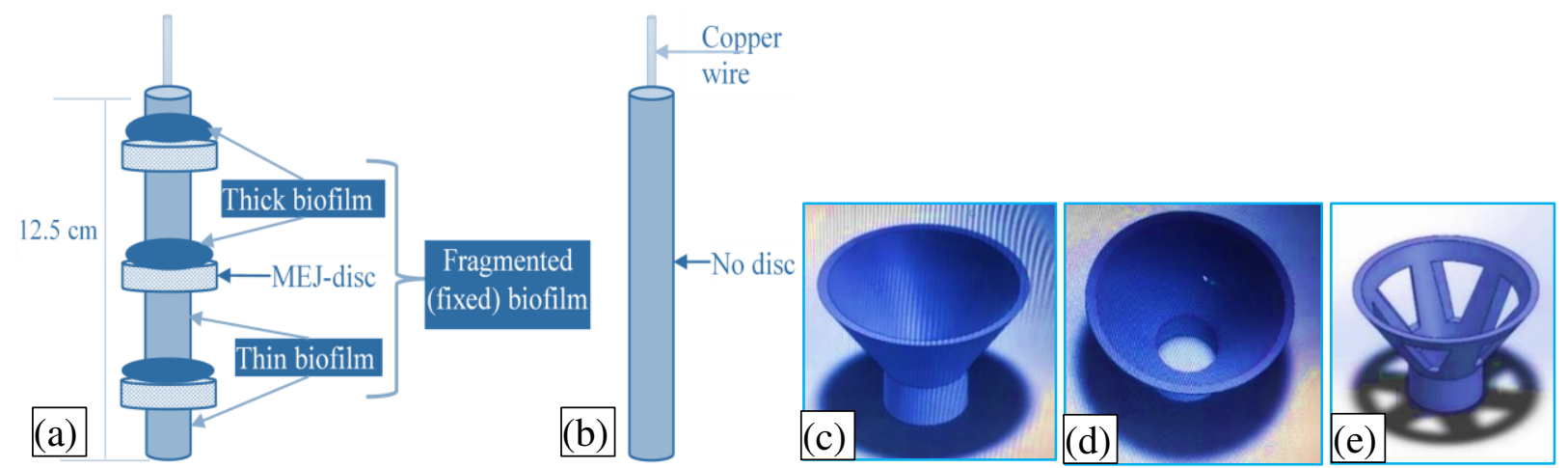


Fig. 3 (a) microbial electrode jacket (MEJ-dish), and non-MEJ-dish (or disc) electrode designed for MFC, and (c-e) a 3D drawing of 3D MEJ-dish used in FAB reactor

As shown in Fig. 4, the FAB setup was designed from a graphite electrode that was inserted into the biosolid supporting substratum (e.g. funnel); which was used to imitate the MEJ-disc for microbial growth support media in FAB reactor development and constructed later on. This setup was inserted into raw domestic wastewater mixed with inoculum (cow dung: domestic wastewater) in a 1:1 ratio. The contents of the reactor were stirred using a magnetic stirrer (DIAB, USA) at speed of $120 \mathrm{rpm}$ (Fig. 4b). For about $10 \mathrm{~min}$ the contents were allotted to settle, then an auto dosing pump (Jebao Inc., China) was used to draw the wastewater from the FAB reactor (Fig. 4c). The setup was allowed to dry in the open air for $24 \mathrm{~h}$ (Fig. 4d), consequently, thick biomass was developed across the electrode (Fig. 4e) that illustrates the retention of biosolids and organic matter across the ring. This concept was adopted to study in a real MFC reactor, in terms of supporting electroactive biofilm growth, enhance voltage generated, and wastewater treatment under different shocking conditions.

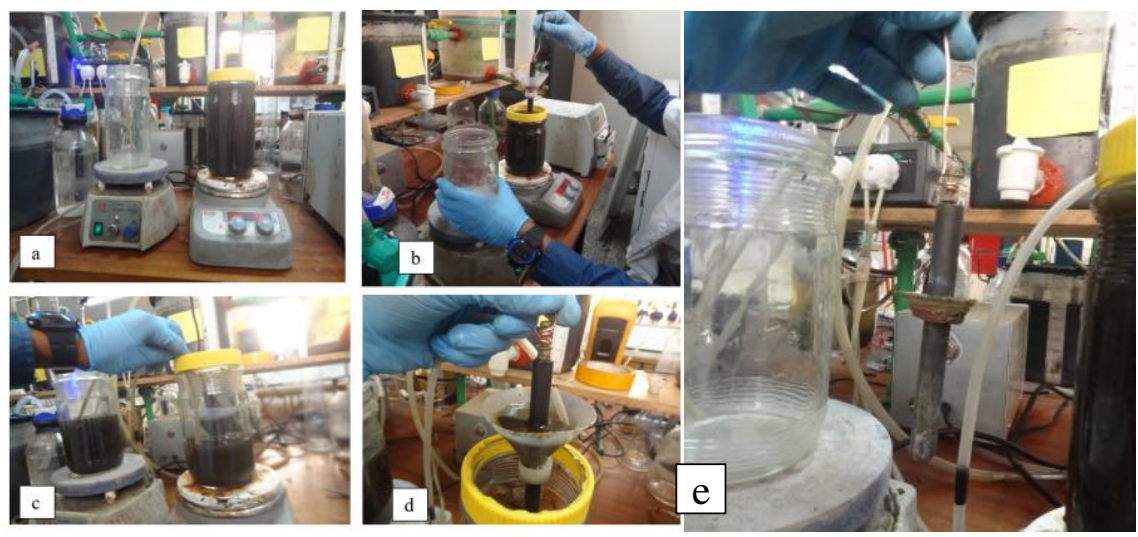

(a) Reactor feed with WW, (b) insertion of MEJ-dish, (c) pumping wastewater, (d) removing the electrode, (e) biomass collected across the electrode

Fig. 4 Demonstration of FAB reactor development process (a-e)

Different types of microbial electrode jacket were used for FAB reactor study. First, smooth materials that discourage the growth of biofilm across the electrode were studied. In this case, a rubber stopper was cut into a circular shape and plugged into the electrode. Second, K3 biofilm carrier with a dimension of $25 \mathrm{~mm}$ X $10 \mathrm{~mm}$ (diameter and depth) supplied from Cz Garden, USA, was drilled at the center and inserted into the graphite electrode. Thirdly, a 3D printer was used to fabricate a special type of 3D MEJ-dish, which consists of the perforated wall for easy movement of nutrients in the reactor and a base that supports the growth of biofilm, as shown in Fig. 5 . 


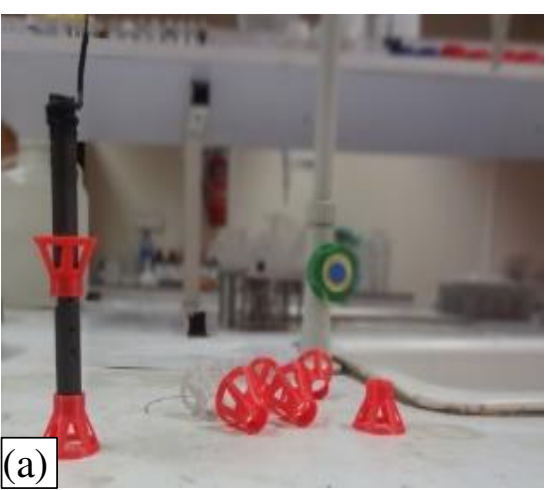

(a) The fabricated 3D MEJ-dish,
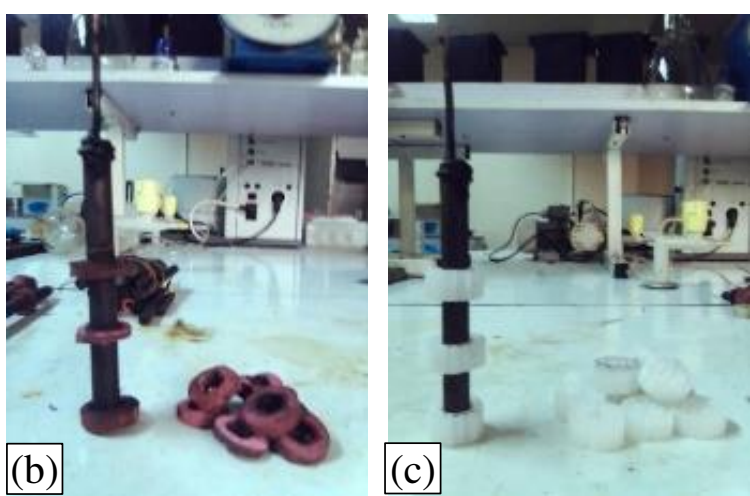

(b) Rubber MEJ-dish, (c) K3 type MEJ-dish

Fig. 5 Different types of microbial electrode jacket (MEJ-dish) used in FAB study

\section{Startup and operation of FAB-MFC}

During startup, inoculum and raw domestic waster were mixed in 1:3 ratio (v/v). Raw wastewater was collected from the primary clarifier of Mickey Leland condominium wastewater treatment plant. The cow manure was used as inoculum in both the optimization (first) and benchtop setup (second).

In the first setup, MFC was optimized based on $\mathrm{pH}$, temperature, and organic loading rate (OLR). The MFC was placed at $27^{\circ} \mathrm{C}$ in a thermostatic bath (DK-98-II/DK-98-II-A, Faithful, China) and stirred using a magnetic stirrer to ensure complete mixing and mass transfer. The $\mathrm{pH}$ of the mixture was adjusted to $6.5,7.5$, and 8.5 using $0.1 \mathrm{M} \mathrm{NaOH}$ and $\mathrm{HCl}$. In the second benchtop setup, MFC operation was studied at room temperature at different $\mathrm{pH}$. The MFCs were routinely monitored for $\mathrm{pH}, \mathrm{COD}$, and voltage generated. Mixed microbial consortia were used to run all the MFC system. The retention time was maintained for a total of 25 days to undertook the experiments.

The electrode surface was scratched with sandpaper and rinsed with tap water to aid the attachment of bacteria. A tiny hole was drilled at one end of the electrode and a peeled part of insulated copper wire was inserted into the holes and firmly coiled around the tip of the anode and cathode electrode. Hence, there were two parts, one end of the copper wire attached to the electrode, and the other section left stranded as shown in Fig. 3. The copper wire part attached with electrode remains inside the reactor, while the stranded part was exposed outside the reactor, and when required connected with a multimeter for measuring voltage. To protect against corrosion or contact with the wastewater, the section of the copper wire that remains inside the reactor was properly sealed with epoxy (Dexter Corp., NJ, USA). Then allowed for $48 \mathrm{~h}$ to dry on open-air before inserting into the reactor. Equal length of copper wire $(10 \mathrm{~cm})$ was used while constructing the reactors.

The anode compartment sparged with nitrogen gas at the startup of the operation. The aqueouscathode was not aerated and fed with tap water, and the lid was loosely coved to allow the flow of air. Graphite electrode was used as both bio anode and cathode. These were two anode reactors with microbial electrode jacket (MEJ-dish) that function as FAB-MFC reactor, two anode reactors without the jacket as MFC, and two as control. The control reactors were fed with similar wastewater as that of the experimental reactors, but sterilized in an autoclave at $120{ }^{\circ} \mathrm{C}$ for 30 
minutes. All MFC tests were conducted in duplicate and performed in a batch mode using a double chamber mini MFC reactor. All the cathode and anode contents were removed between different experimental parameters. Before each experiment, the cathode was replaced with a fresh solution. A new salt bridge was used during the change of each operational parameter.

Finally, all gas and water valves were checked for proper functioning before installing to the reactors. The same gas pipe, in thickness and length, was attached to all the reactors to avoid any biased contribution from the setup. Gasbags were properly emptied (squeezed) and connected to the gas outlet port at the proper location on the anode rector. During and after water sampling, all anode reactors were sparged with nitrogen gas before starting the operation. Similar to the anaerobic reactor, the coverlid including all other openings, and tube junctions of the anode chamber were properly closed and sealed with a gasket maker (Abro chemicals, USA). All the reactors and valves were routinely monitored and if necessary maintained.

\section{Analysis of MFCs}

The open-circuit voltage (OCV) was measured using a multimeter (XL830L). COD and pH were monitored using the standard method (APHA 2005) and UV-Vis spectrophotometer was used to determine those chemical compositions (DR 6000, HACH, USA). The ANOVA test was used to determine the significant difference $(\mathrm{p}<0.05)$ between the parameters in the experimental setup.

\section{Operational parameters calculation}

Organic loading rate (OLR)

The organic loading rate is the amount of organic matter that was feed into the reactor within a specified time ( $\mathrm{Lim}$ et al. 2008). It is measured in $\mathrm{kg} \mathrm{COD} / \mathrm{m}^{3}$ per day. The OLR was calculated using Equation 1.

$$
\mathrm{OLR}=\frac{\mathrm{Q} \times \mathrm{C}_{\mathrm{i}}}{\mathrm{V}_{\text {reactor }}}
$$

where $\mathrm{Q}$ is the wastewater flow rate $\left(\mathrm{m}^{3} /\right.$ day), $C_{i}$ is COD concentration in the inflow water $\left(\mathrm{kg} / \mathrm{m}^{3}\right)$, and $\mathrm{V}_{\text {reactor }}$ is the working volume of the reactor $\left(\mathrm{m}^{3}\right)$

\section{Process performance calculation}

The reactor performance was measured in terms of voltage generation efficiency. The removal of COD is calculated based on Equation 2.

$$
\mathrm{R}(\%)=\left(1-\frac{\mathrm{C}_{\text {out }}}{\mathrm{C}_{\text {in }}}\right) \times 100 \%
$$

where $\mathrm{R}$ is removal efficiency $(\%), \mathrm{C}_{\text {in }}$ is an influent concentration $(\mathrm{mg} / \mathrm{L})$, and $\mathrm{C}_{\text {out }}$ is an effluent concentration $(\mathrm{mg} / \mathrm{L})$ 


\section{- Results and discussion}

\section{Wastewater and inoculum characterization}

The organic and nutrient composition of the collected raw wastewater and inoculum are presented in Table 1. According to the result, the $\mathrm{pH}$ (6.5-7.5) values of both the raw wastewater and inoculum are in a favorable range for anaerobic microbial growth (Liu et al. 2008). Additionally, the lower buffering capacity of the raw domestic wastewater might be due to lower alkalinity content $\left(35.01 \mathrm{mg} / \mathrm{L}\right.$ as $\left.\mathrm{CaCO}_{3}\right)$.

The solid content of wastewater is an important parameter that affects the treatment efficiency. The total solids (TS) found in wastewater are either in volatile or fixed form, which is further classified into suspended or dissolved solids. However, the most determinant in wastewater treatment is volatile solids (VS), as it shows the microbial biomass. Based on Table 1, the TS and VS concentration of the inoculum wastewater was four times higher than the raw domestic wastewater. The mean TCOD observed in raw domestic wastewater and inoculum was 795.34 $\mathrm{mg} / \mathrm{L}$ and $1678.29 \mathrm{mg} / \mathrm{L}$, respectively. This value was within typical wastewater COD content (Edwin et al. 2014). Similar COD concentrations range were reported by Puig et al. (2010).

Table 1 Characteristics of raw and inoculum wastewater used in this study

\begin{tabular}{llll}
\hline Parameters & Raw wastewater & Inoculum & Influent \\
\hline $\mathrm{pH}$ & $7.51 \pm 0.07$ & $6.43 \pm 0.06$ & $7.42 \pm 0.26$ \\
Total Alkalinity $\left(\mathrm{mg} / \mathrm{L}\right.$ as $\left.\mathrm{CaCO}_{3}\right)$ & $35.01 \pm 2.87$ & $144 \pm 4.59$ & $84.29 \pm 0.37$ \\
Total Solid $(\mathrm{mg} / \mathrm{L})$ & $157.93 \pm 28.29$ & $3,277.35 \pm 416.2$ & $2396.52 \pm 0.19$ \\
Volatile Solid $(\mathrm{mg} / \mathrm{L})$ & $366.14 \pm 58.99$ & $1,559.62 \pm 210.89$ & $793.86 \pm 0.48$ \\
Total COD $\left(\mathrm{mg} \mathrm{O}_{2} / \mathrm{L}\right)$ & $795.34 \pm 160.01$ & $9,760.4 \pm 550.97$ & $1678.29 \pm 0.72$ \\
Ammonia $(\mathrm{mg} \mathrm{NH}-\mathrm{N} / \mathrm{L})$ & $19.75 \pm 1.77$ & $272.35 \pm 11.97$ & $152.62 \pm 0.60$ \\
Total phosphorus $(\mathrm{mg} \mathrm{P} / \mathrm{L})$ & $8.12 \pm 1.59$ & $21.64 \pm 0.9$ & $11.27 \pm 0.15$ \\
\hline
\end{tabular}

\section{Optimization of FAB-MFC}

After the FAB-MFC operation, the reactors were dismantled to observe the growth and development of biofilm over the electrodes. As shown in Fig. 6, bioanode with MEJ+ develops thick observable biofilm that surrounds the electrode as compared with electrode lacking the MEJ disc (MEJ-).

A 3D conical shape FAB with the perforated wall was printed using a 3D printer. After the end of each experiment, the reactors were carefully opened to observe the development of biofilm across the electrode. In FAB reactors with microbial electrode jacket (MEJ) well and fixed biofilms were observed in a stratified (fragmented) manner across the electrode, as shown in Fig. 6. While in electrode lacking the MEJ-dish no such type of biofilm growth and development was observed. 

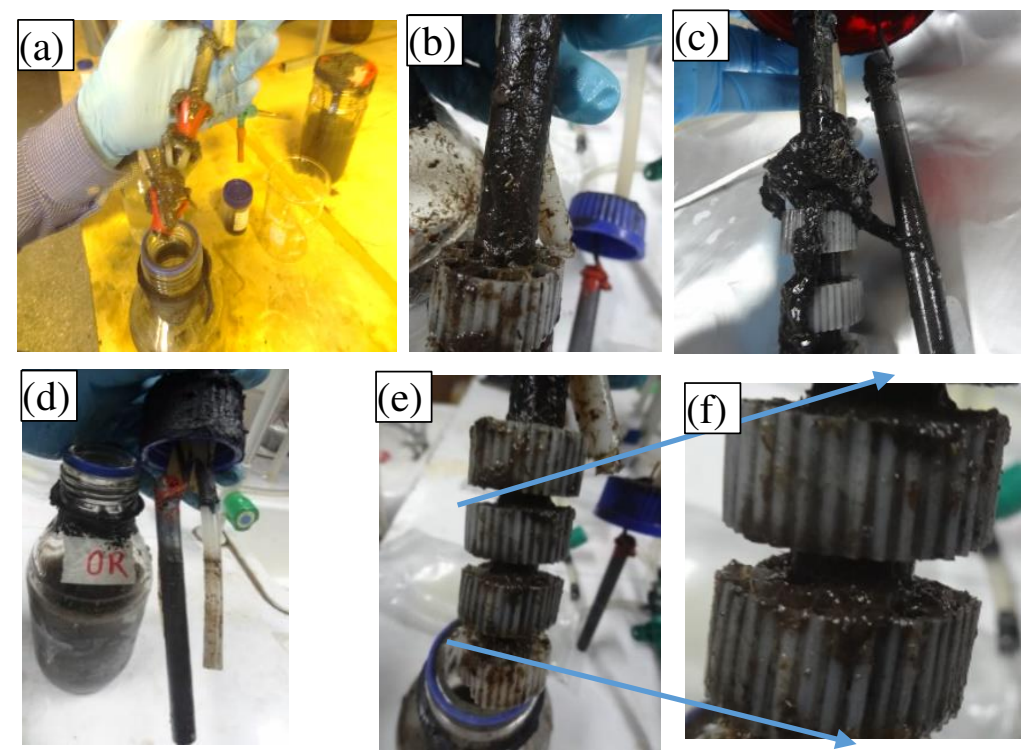

Fig. 6 Biofilm growth and development over a) 3D MEJ dish, b) K3 FAB, and c) biofilm growth over electrode with K3 MEJ-dish

However, in future studies, it might be very essential to determine the number of MEJ-dish per electrode and the sludge volume nature of the wastewater. This could potentially result in excessive growth of biofilm or promotes electron scavengers (endoelectrogens). Not only does this affect the biofilm formation for better volt generation and COD removal; but also determines the type of MEJ dish used in the FAB reactor. Because, a certain type of MEJ-dish covers some part of the electrode surface, that minimizes the active surface for electron transfer and lowers the electrode working surface area. However, MEJ-dish such as K3 based FAB reactors might promote the development of exoelectrogens without affecting the working surface area. This is because the junction point where the MEJ-dish holds the electrode was uncovered for exoelectrogens development.

\section{.1.1 Bioelectricity generation}

The performance of each MFC reactor in terms of daily voltage generation and COD removal are shown in Fig. 7. During the first 5 days, the generated voltage was significantly $(\mathrm{p}<0.05)$ higher in all FAB-MFC than non-FAB-MFC. This could be due to thick electroactive biofilms (EABs) were developed over the FAB electrode as compared with non-FAB-MFC reactor. This thick film may also contain an extracellular polymer substance (EPS), which might be an electro conductor and contribute to MFC electron transport chain. The electrochemical nature of these polymers could be unique compared with non-exoelectrogens. These characteristics are very important in developing thick electroactive biofilm. However, the clear-cut understanding of electron transfer (ET) mechanisms in EABs requires further research (Li et al., 2014). Recent publications revealed, a network of the nanowire, cytochromes, and some conductive proteins involved in the long-range ET (electro transfer) through cell-to-cell or cell to the electrode (Patil et al. 2012). The high voltage observation in the FAB reactor could be due to the cell-to-cell metallic-like conductivity than direct electron tunneling through $c$-type cytochrome to the electrode. 
The microbial activity to generate voltage changes with $\mathrm{pH}$ (Borole et al. 2011), especially the FAB system was important in near neutral and basic $\mathrm{pH}$. In support of the hypothesis, regardless of $\mathrm{pH}$ variation from 6.5 to 7.5 the FAB enables to obtain the maximum possible voltage, which was not observed in MFC lacking the FAB system. At alkaline $\mathrm{pH} 8.5$, the voltage generation of the MFC deprived of MEJ-dish was significantly higher than the FAB system. This implies, the formation of biofilm across the electrode is not only important for electricity generation but also mediating favorable conditions for electroactive biofilm microorganisms. This could be creating anaerobic environment, minimizing the effect of $\mathrm{pH}$ for exoelectrogens, and probably providing suitable intermediate metabolites. Overall, there might be a mutualistic effect within the biofilm across the anode microbiota.

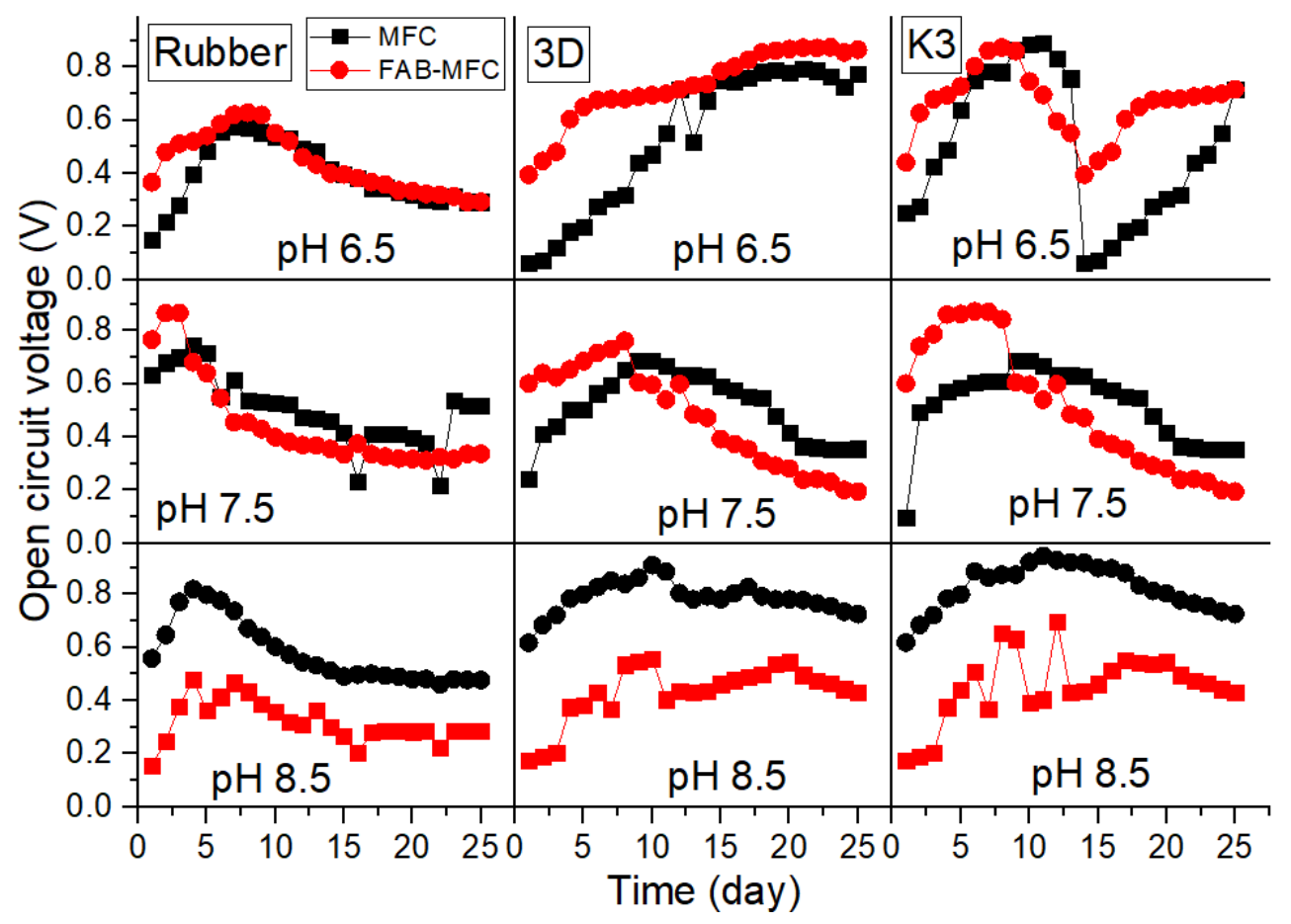

Fig. 7 Open circuit voltage result of rubber, 3D, and $\mathrm{K} 3$ based $\mathrm{FAB}$ prototype reactor $\left(27^{\circ} \mathrm{C}\right)$

\section{.1.2 Treatment performance}

To compare the COD removal in FAB-MFC with non-FAB setup, the COD removal in the anode reactor was separately measured by placing them in separate reactors under open-circuit conditions at $27{ }^{\circ} \mathrm{C}$ fed with cow manure as inoculum and domestic wastewater. The COD removal in the FAB-MFC was significantly increased relative to MFC during the first five days. This shows the formation of biofilm across the anode electrode might contribute to the removal of COD. 


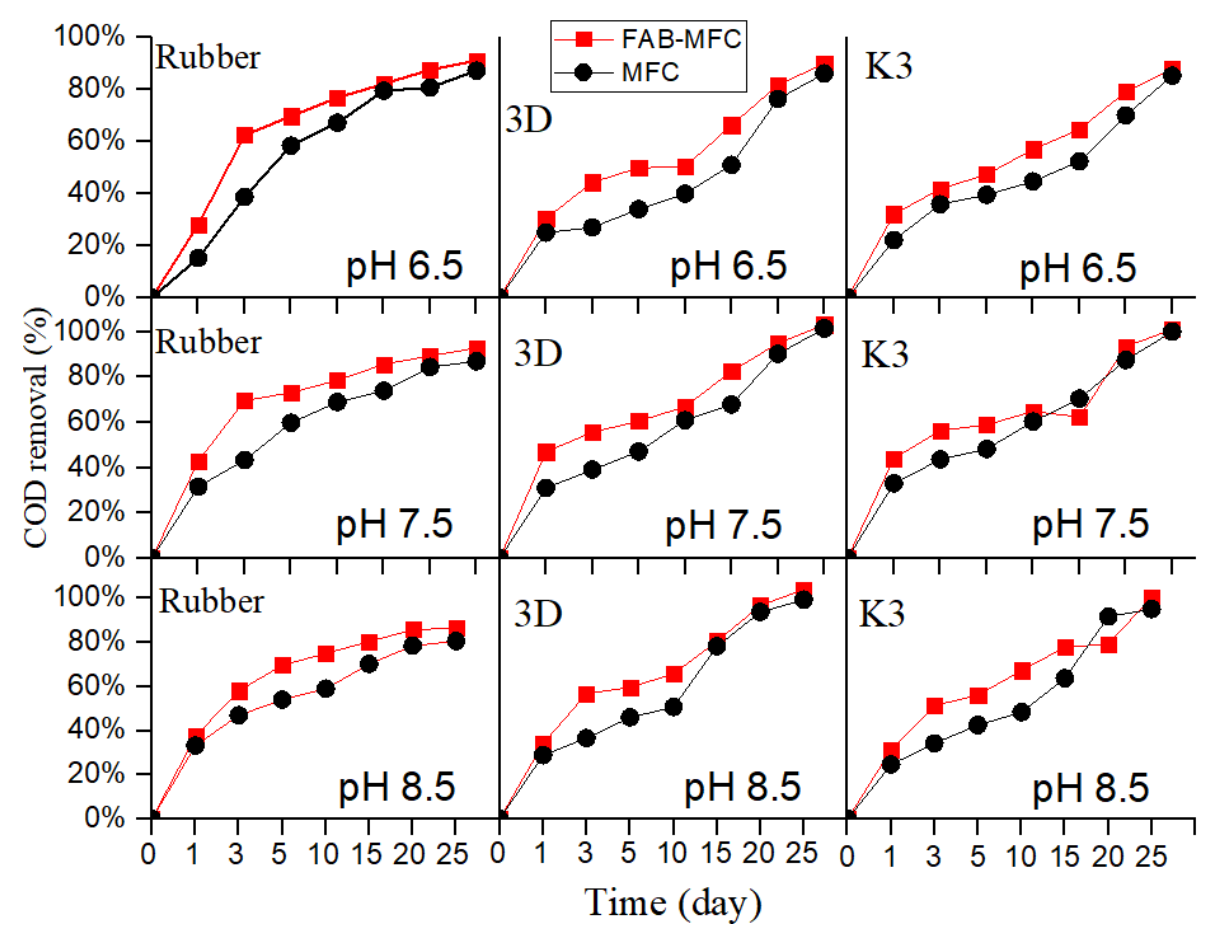

Fig. 8 COD removal efficiency in MFC system

There were contradictory effects of enhancing biofilm development across the electrode based on the $\mathrm{pH}$ of the substrate. The voltage generation was significant at acidic and near-neutral $\mathrm{pH}$, but across all $\mathrm{pH}$ values under study, the COD removal was significantly higher within 3-10 days in the supported growth reactor (FAB-MFC) relative to the one that deprives (MFC). However, as the reactor age increases there was no observable difference, which entails biofilms slowly start to develop in the non-FAB reactor to remove the COD. Therefore, to enhance the COD removal within a limited time frame the $\mathrm{FAB}$ could be advisable, particularly at higher $\mathrm{pH}$; whereas, the voltage generation was another important concern. Hence, a hybrid reactor that contains both FAB and non-FAB in a single MFC reactor might maximize the two contradictory points at higher $\mathrm{pH}$. Therefore, further studies are required to clearly understand the cause-effect relationship.

\section{Bench-scale FAB-MFC}

The maximum 0.87 volts was generated in FAB-MFC as compared with the non-FAB-MFC system, as shown in Fig. 9. The system might minimize DO shock to anode respiring EABs (anaerobic microorganisms), avail soluble intermediate break down of metabolites to $\mathrm{EAB}$, and enable to withstand $\mathrm{pH}$ difference (>7) through mutualistic effect. However, the long period operation of MFC might develop dead biomass on the electrode, which could forbid active anode respiring biomass growth to the surface of the electrode. The electrical conductivity of inactive EABs mass due to pili or the nanowire over the electrode surface was not reported. Another challenge to scale up the FAB-MFC was the reuse of the parts without clogging after long-term operation. These could block electron flow from EABs to the electrode and finally results in decreasing in the system voltage generation performance. COD removal in bench-scale FAB-MFC setup was significantly higher as compared with non-FAB-MFC. 


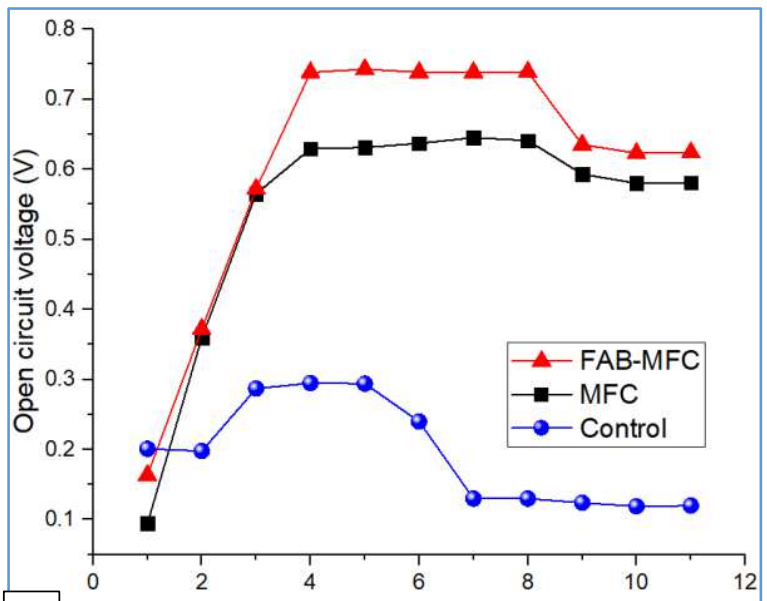

(a)

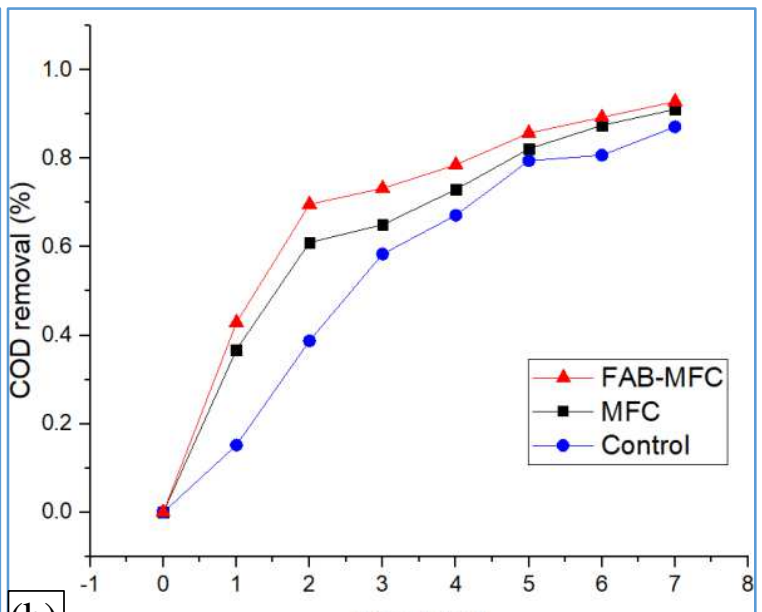

(b)

Fig. 9 Lab-scale benchtop MFC (a) voltage generated, and (b) COD removal (\%)

\section{- Conclusions}

In this study, the fragmented electroactive microbial fuel cell (FAB-MFC) reactor was designed and invented to simultaneously increase electricity generation and COD removal. The microbial electrode jacket-dish (MEJ-dish) was used as fixed electrode biofilm support media to grow fragments of biofilm across the anode electrode. The effect of FAB-MFC on electricity generation and treatment performance was investigated using different $\mathrm{pH}\left(6.5,7.5\right.$, and 8.5) at $27{ }^{\circ} \mathrm{C}$. Residential domestic wastewater was used as substrate and cow manure as an inoculant. The study result shows, the FAB-MFC significantly increases the voltage generation as compared with nonFAB-MFC. In agreement with the hypothesis, the volt generation capacity of FAB-MFC was not affected due to the substrate $\mathrm{pH} 6.5$ to 7.5 variation; but, at alkaline $\mathrm{pH} 8.5$, the non-FAB reactors perform better than the FAB system. In contrast, the COD removal was improved regardless of $\mathrm{pH}$ difference (6.5-8.5). This indicates all the COD removal was not directly associated with voltage generation and exoelectrogens biofilm formation either facilitate the COD removal. In turn, this might be affected by the solid and COD content of the domestic wastewater that might require further studies. The benchtop experimental study also confirms the optimization finding, where the voltage generation and COD removal were higher in the FAB system. Overall, the FAB reactor containing the microbial electrode jacket dish (MEJ-dish) significantly improves the bioelectricity generation and COD removal within a limited $\mathrm{pH}$ range. However, it might be affected by the nature of the inoculant and wastewater composition that requires further studies.

\section{Abbreviations}

FAB: fragmented electroactive biofilm; MEJ-dish: microbial electrode jacket dish; MFC: microbial fuel cell; FAB-MFC: fragmented electroactive microbial fuel cell;

\section{Acknowledgments}

The authors would like to thank Addis Ababa University, Center for environmental science, and Mettu University for support to undertake this research.

\section{Authors' contributions}


TA design the experimental setup and run the analysis. SL supervised and evaluated the work and participated during the design and development of the study. All authors read and approved the final manuscript

\section{Funding}

Not applicable

\section{Availability of data and materials}

The data sets used in this study are available from the corresponding author on reasonable request

Ethical approval and consent to participate

Not applicable.

\section{Consent for publication}

Not applicable.

\section{Competing interests}

The authors declare that no conflict of interest

\section{References}

Ankur B, Shipra S (2018) Microbial Fuel Cell: an efficient method to utilize prokaryotic potential to engender reliable energy Journal of Microbial \& Biochemical Technology 10:69-75

APHA (2005) Standard methods for the examination of water and wastewater. 21st edn. American Public Health Association (APHA), American Water Works Association (AWWA), and Water Environmet Federation, Washington DC, USA

Arbianti R, Surya Utami T, Leondo V, Andyah Putri S, Hermansyah H (2018) Effect of biofilm and selective mixed culture on microbial fuel cell for the treatment of tempeh industrial wastewater MS\&E 316:012073

Borole AP, Reguera G, Ringeisen B, Wang Z-W, Feng Y, Kim BH (2011) Electroactive biofilms: current status and future research needs Energy Environ Sci 4:4813-4834

Edwin GA, Gopalsamy P, Muthu N (2014) Characterization of domestic gray water from point source to determine the potential for urban residential reuse: a short review Applied Water Science 4:39-49 doi:10.1007/s13201-013-0128-8

Erable B, Duţeanu NM, Ghangrekar MM, Dumas C, Scott K (2010) Application of electro-active biofilms Biofouling 26:57-71

Flimban SGA, Ismail IMI, Kim T, Oh S-E (2019) Overview of recent advancements in the microbial fuel cell from fundamentals to applications: design, major elements, and scalability Energies 12:3390 doi:10.3390/en12173390

Guo Y et al. (2020) Simultaneous wastewater treatment and energy harvesting in microbial fuel cells: an update on the biocatalysts RSC Advances 10:25874-25887 doi:10.1039/d0ra05234e 
He L, Du P, Chen Y, Lu H, Cheng X, Chang B, Wang Z (2017) Advances in microbial fuel cells for wastewater treatment Renewable and Sustainable Energy Reviews 71:388-403 doi:https://doi.org/10.1016/j.rser.2016.12.069

Jang JK, Pham TH, Chang IS, Kang KH, Moon H, Cho KS, Kim BH (2004) Construction and operation of a novel mediator-and membrane-less microbial fuel cell Process Biochem 39:1007-1012

Koroglu EO, Yoruklu HC, Demir A, Ozkaya B (2019) Scale-up and commercialization issues of the MFCs: challenges and implications. In: Microbial electrochemical technology. Elsevier, pp 565-583

Kumar R, Singh L, Zularisam AW, Hai FI (2018) Microbial fuel cell is emerging as a versatile technology: a review on its possible applications, challenges and strategies to improve the performances International Journal of Energy Research 42:369-394 doi:10.1002/er.3780

Lim SJ, Kim BJ, Jeong CM, Choi JD, Ahn YH, Chang HN (2008) Anaerobic organic acid production of food waste in once-a-day feeding and drawing-off bioreactor Bioresour Technol 99:7866-7874 doi:10.1016/j.biortech.2007.06.028

Liu CF, Yuan XZ, Zeng GM, Li WW, Li J (2008) Prediction of methane yield at optimum pH for anaerobic digestion of organic fraction of municipal solid waste Bioresour Technol 99:882888 doi:10.1016/j.biortech.2007.01.013

Liu H, Logan BE (2004) Electricity generation using an air-cathode single chamber microbial fuel cell in the presence and absence of a proton exchange membrane Environ Sci Technol 38:4040-4046 doi:10.1021/es0499344

Logan BE et al. (2006) Microbial fuel cells: methodology and technology Environ Sci Technol 40:5181-5192 doi:10.1021/es0605016

Malvankar NS et al. (2011) Tunable metallic-like conductivity in microbial nanowire networks Nature Nanotechnology 6:573-579 doi:10.1038/nnano.2011.119

Mancílio LBK et al. (2020) Unusual microbial community and impact of iron and sulfate on microbial fuel cell ecology and performance Current Research in Biotechnology 2:64-73 doi:10.1016/j.crbiot.2020.04.001

Michie IS, Dinsdale RM, Guwy AJ, Premier GC (2020) Electrogenic biofilm development determines charge accumulation and resistance to $\mathrm{pH}$ perturbation Energies 13:3521 doi:10.3390/en13143521

Patil SA, Hägerhäll C, Gorton L (2012) Electron transfer mechanisms between microorganisms and electrodes in bioelectrochemical systems Bioanalytical Reviews 4:159-192 doi:10.1007/s12566-012-0033-x

Puig S, Serra M, Coma M, Cabré M, Balaguer MD, Colprim J (2010) Effect of pH on nutrient dynamics and electricity production using microbial fuel cells Bioresour Technol 101:9594-9599 doi:10.1016/j.biortech.2010.07.082

Santoro C, Arbizzani C, Erable B, Ieropoulos I (2017) Microbial fuel cells: from fundamentals to applications. A review J Power Sources 356:225-244 doi:10.1016/j.jpowsour.2017.03.109

Sevda S, Sreekrishnan TR (2012) Effect of salt concentration and mediators in salt bridge microbial fuel cell for electricity generation from synthetic wastewater Journal of Environmental Science and Health, Part A 47:878-886

Strycharz-Glaven SM, Snider RM, Guiseppi-Elie A, Tender LM (2011) On the electrical conductivity of microbial nanowires and biofilms Energy Environ Sci 4:4366-4379

Strycharz S, Tender L (2012) Reply to the "comment on "on electrical conductivity of microbial nanowires and biofilms" by N. S. Malvankar, M. T. Tuominen and D. R. Lovley, Energy 
Environ. Sci., 2012, 5, DOI: 10.1039/c2ee02613a Energy Environ Sci 5:6250-6255 doi:10.1039/C2EE03056J

Sun D, Chen J, Huang H, Liu W, Ye Y, Cheng S (2016) The effect of biofilm thickness on electrochemical activity of Geobacter sulfurreducens Int J Hydrogen Energy 41:1652316528 doi:10.1016/j.ijhydene.2016.04.163

Ter Heijne A, Pereira MA, Pereira J, Sleutels T (2020) Electron storage in electroactive biofilms Trends Biotechnol

Ucar D, Zhang Y, Angelidaki I (2017) An overview of electron acceptors in microbial fuel cells Front Microbiol 8 doi:10.3389/fmicb.2017.00643

Vicari F, D'Angelo A, Galia A, Quatrini P, Scialdone O (2016) A single-chamber membraneless microbial fuel cell exposed to air using Shewanella putrefaciens J Electroanal Chem 783:268-273 doi:10.1016/j.jelechem.2016.11.010

Yang J, Cheng S, Li P, Huang H, Cen K (2019) Sensitivity to oxygen in microbial electrochemical systems biofilms iScience 13:163-172 doi:10.1016/j.isci.2019.01.022 
Figures
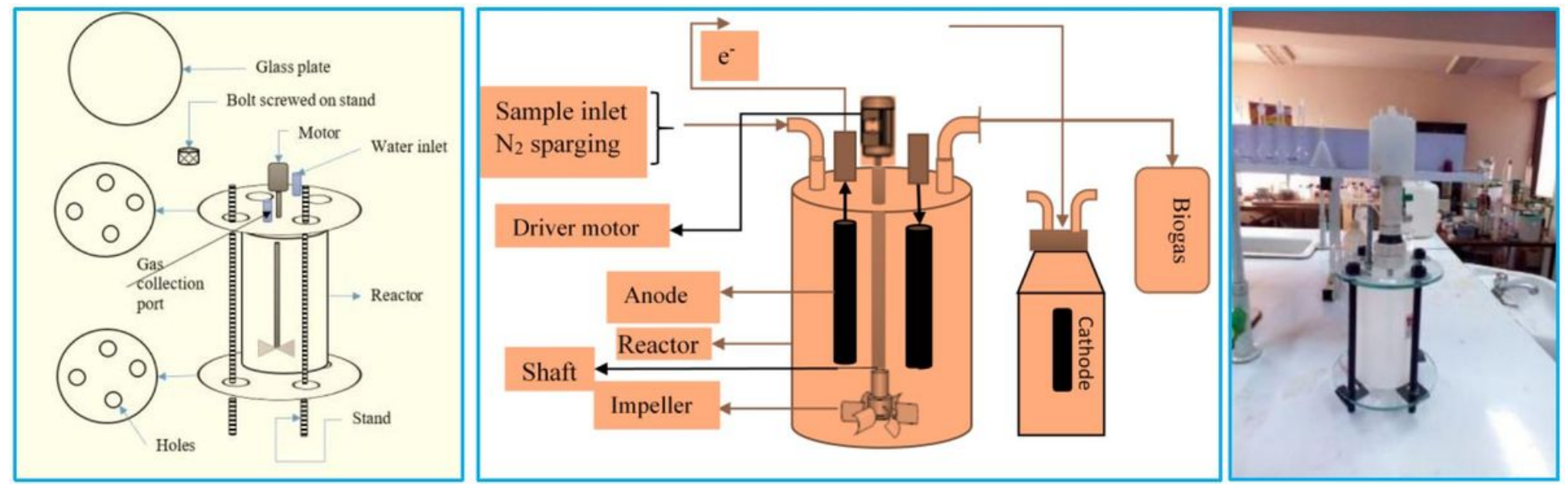

Figure 1

Schematic diagram of mini benchtop microbial fuel cell reactor (mbMFC), the constructed lab-scale microbial fuel cell
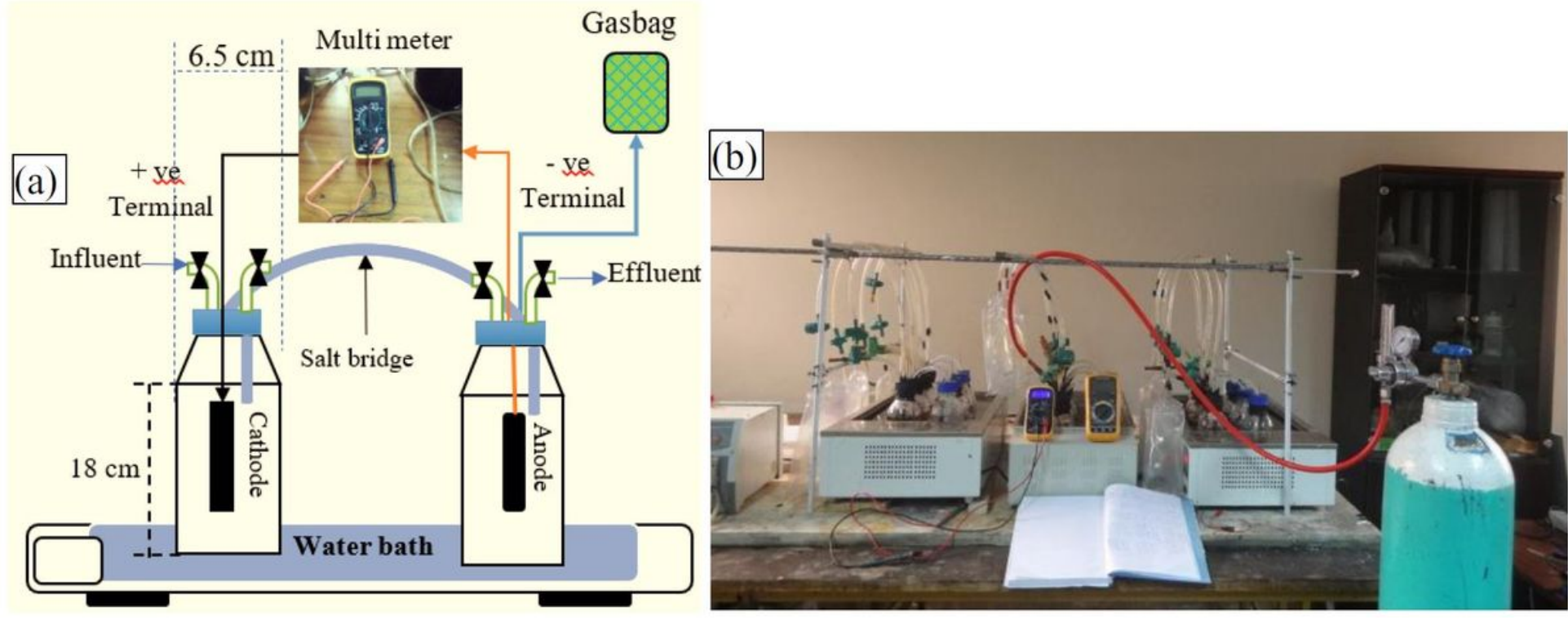

Figure 2

Schematic diagram of semi-continuous H-type FAB-MFC optimization setup 


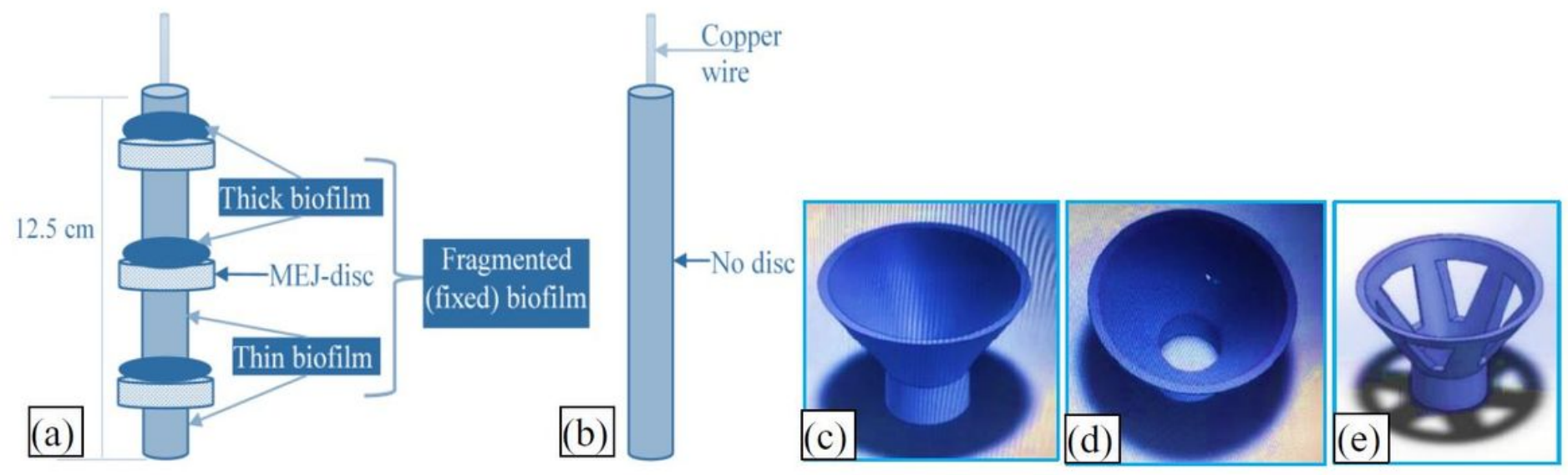

Figure 3

(a) microbial electrode jacket (MEJ-dish), and non-MEJ-dish (or disc) electrode designed for MFC, and (ce) a 3D drawing of 3D MEJ-dish used in FAB reactor
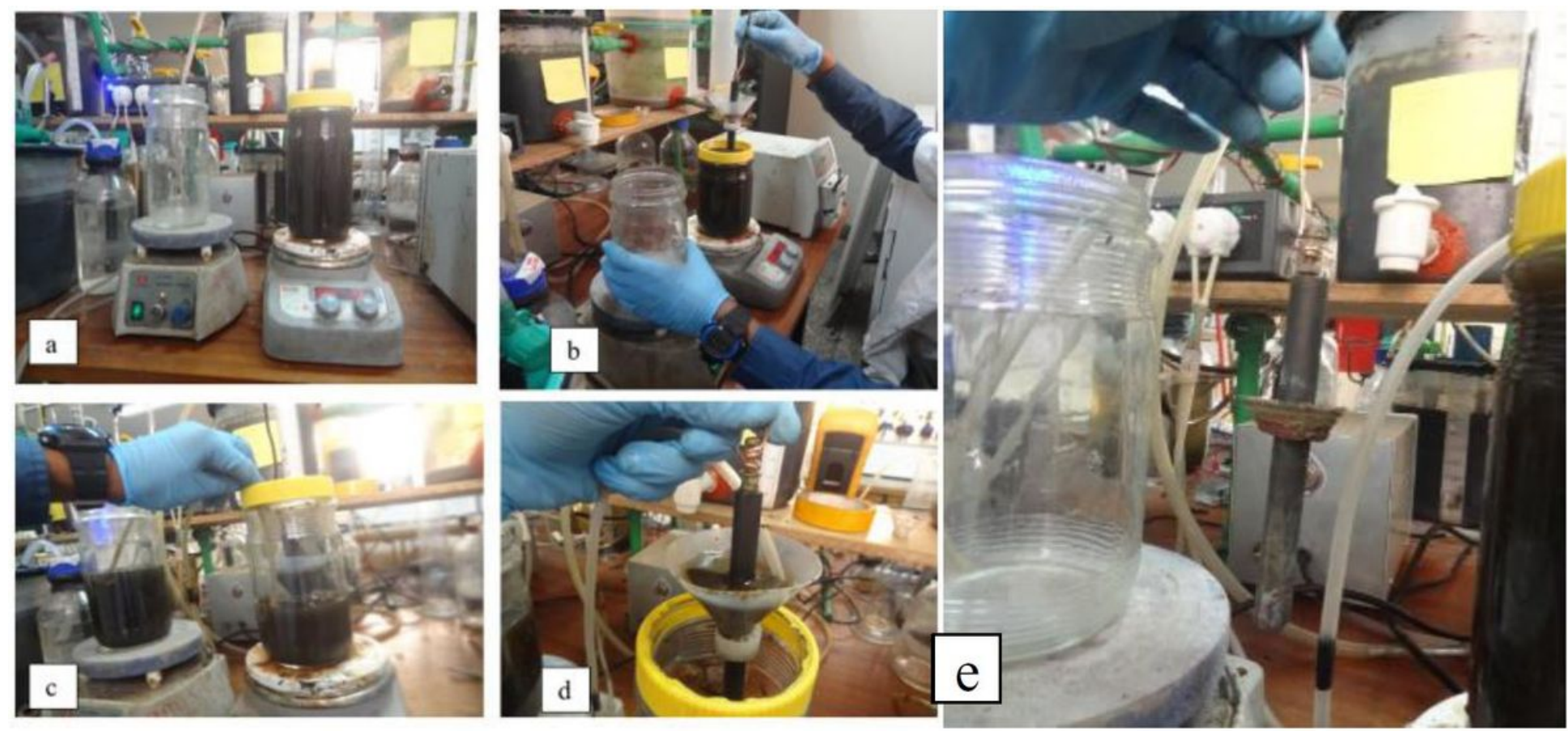

Figure 4

Demonstration of FAB reactor development process (a-e). (a) Reactor feed with WW, (b) insertion of MEJdish, (c) pumping wastewater, (d) removing the electrode, (e) biomass collected across the electrode 

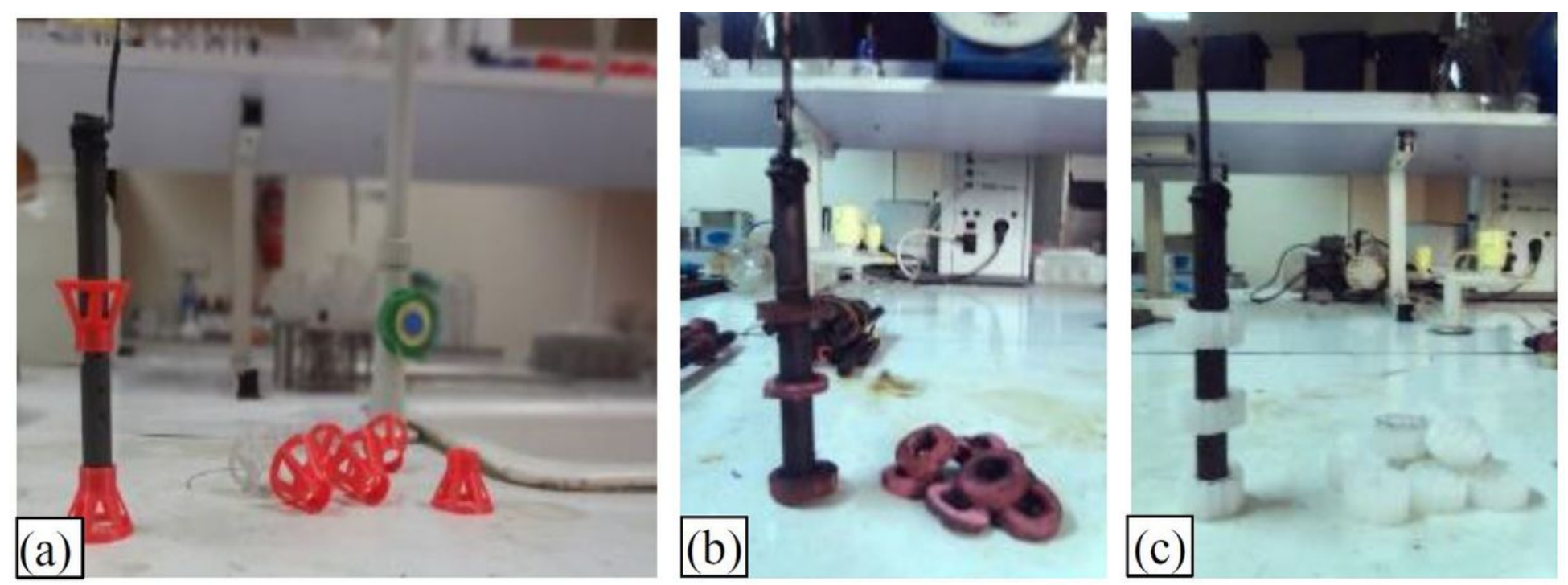

Figure 5

Different types of microbial electrode jacket (MEJ-dish) used in FAB study. (a) The fabricated 3D MEJdish, (b) Rubber MEJ-dish, (c) K3 type MEJ-dish
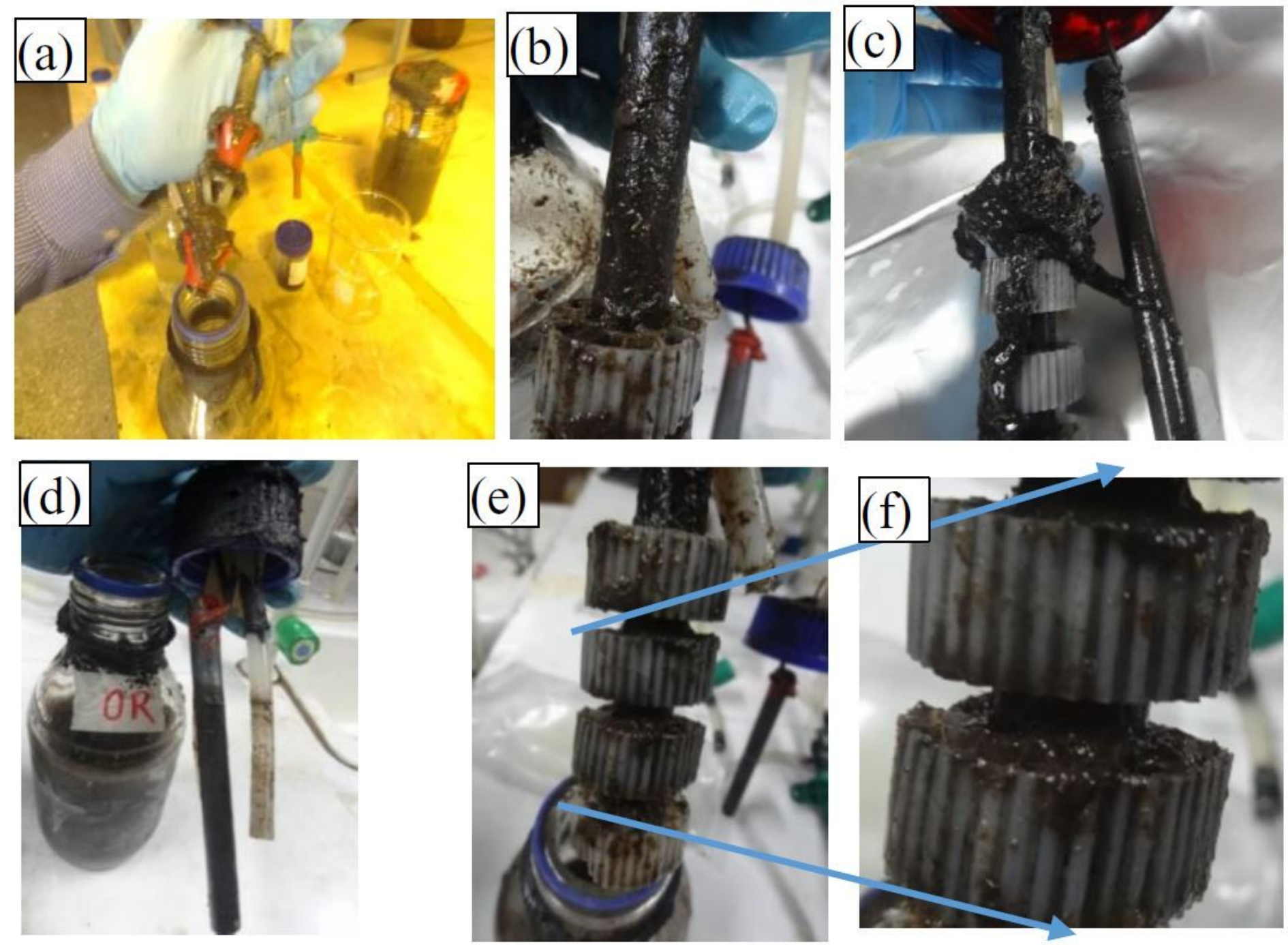
Figure 6

Biofilm growth and development over a) 3D MEJ dish, b) K3 FAB, and c) biofilm growth over electrode with K3 MEJ-dish

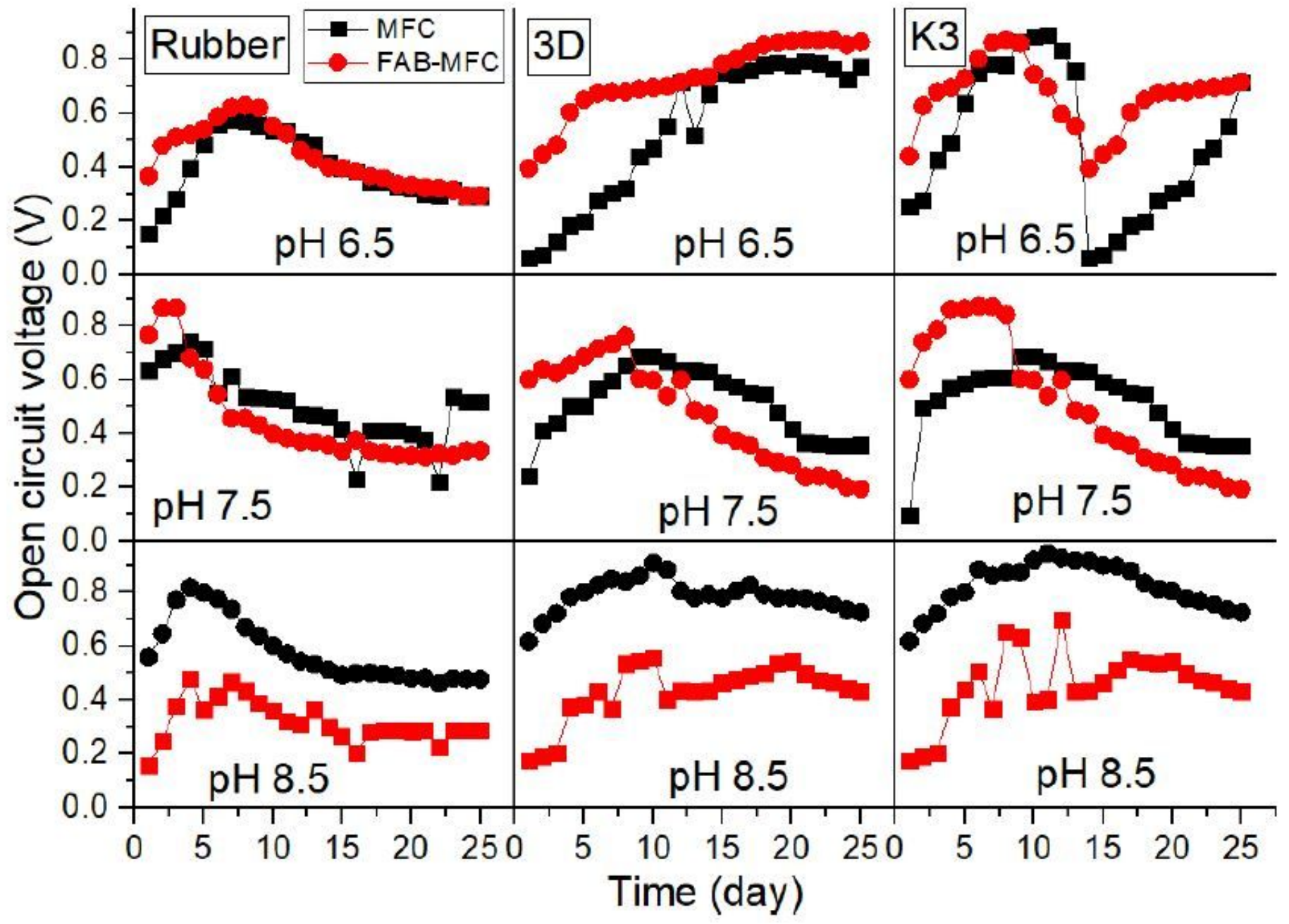

Figure 7

Open circuit voltage result of rubber, 3D, and K3 based FAB prototype reactor $(27 \rrbracket)$ 


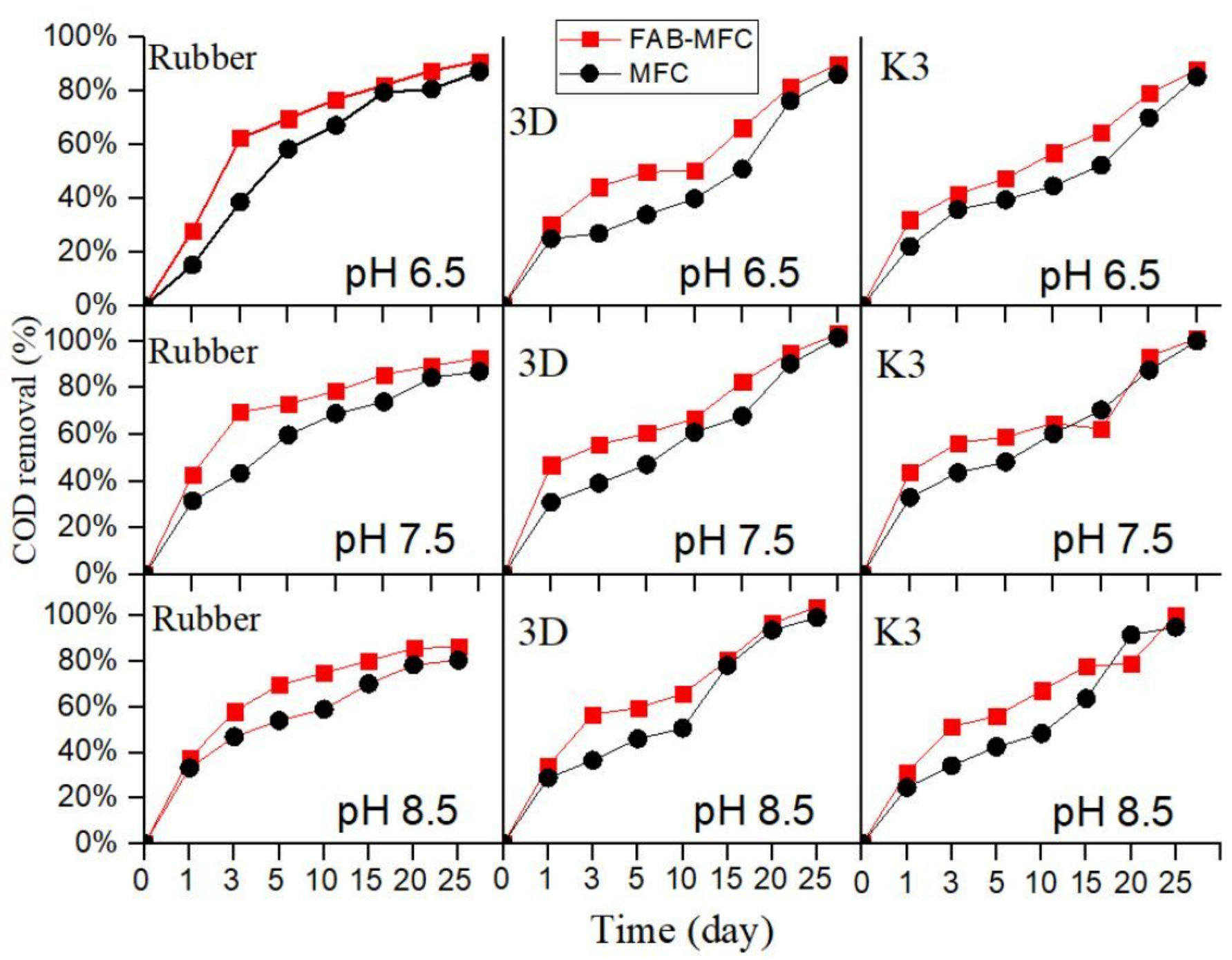

Figure 8

COD removal efficiency in MFC system
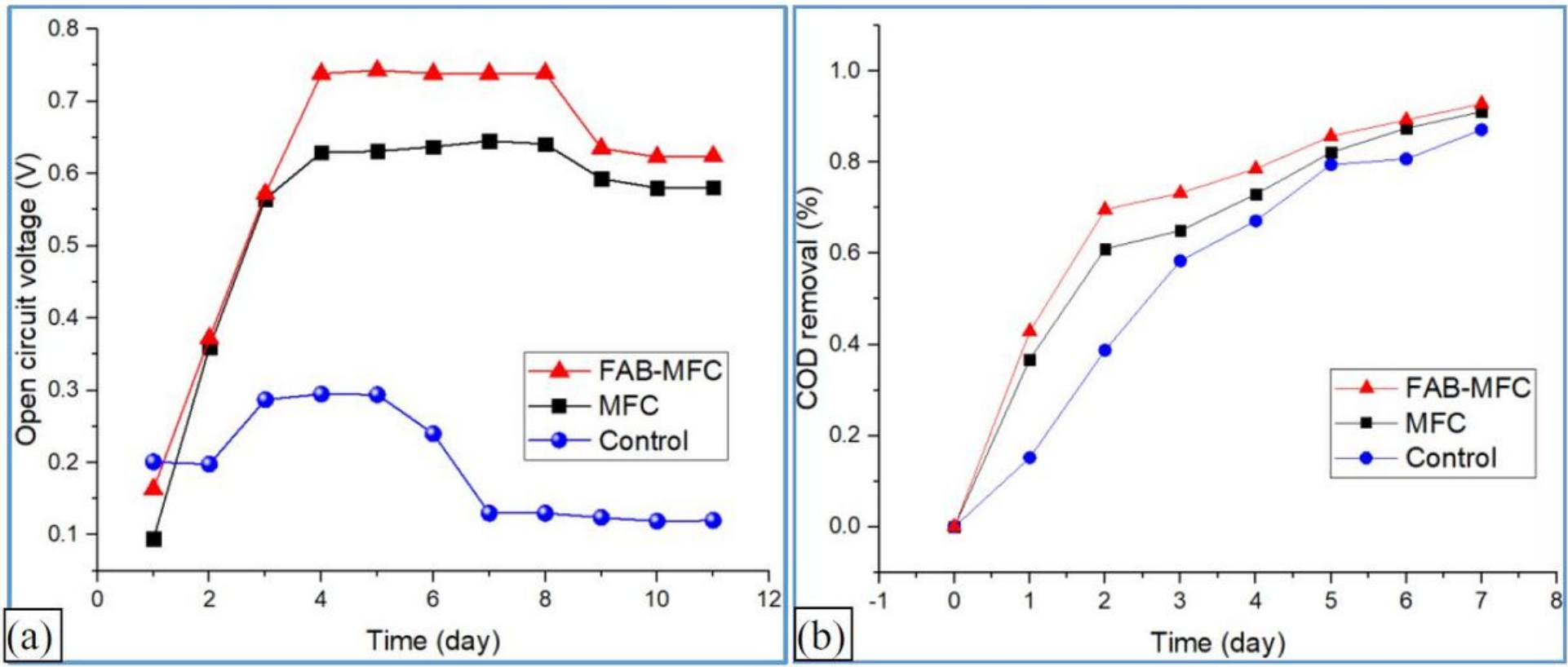
Figure 9

Lab-scale benchtop MFC (a) voltage generated, and (b) COD removal (\%) 